\title{
Stone Age Archaeological Sites in the Landscape. Monumentalisation of Sites on the South Korea Example ${ }^{1}$
}

Dozens of new archaeological sites are being discovered around the world every year. Most of these discoveries are well protected and secured. Research documentation and portable artifacts are moved to museums and research institutes. Some of them are examined and meticulously analyzed, and the resultant research papers published. However, the most interesting archaeological sites that contribute most to science are only sometimes provided with special protection. Prehistoric strongholds, fortified settlements or megalithic tombs are sporadically reconstructed on the site of excavations and are a subject to legal protection functioning as parks or archaeological reserves, permanently inscribing in the regional landscape. For example, in European tourism, such activities are considered the most attractive ways to illustrate and tell the story of the history of the region and have the greatest impact on tourists (e.g. Rajewski 1964; Hensel 1973; The Reconstructed Past.. 2004). Everything that has been mentioned above is related to the use of archaeological sites for educational, tourist and promotional purposes.

However, what about archaeological sites, the remains of which are not visible in the landscape?

I This article is based on research conducted by the author at the archaeological sites discussed in this article. Since 2015, the author of the article has been associated with the Korean scientific program, "Suyanggae and Her Neighbours". The main purpose of these cyclical conferences is to exchange experiences and determine the main directions of development of research into the Stone Age in the world, with a focus on the Far East. So far, he has had the pleasure of being in South Korea twice. He has also had the honor to meet Professor Lee Yung-Jo and Professor Kidong Bae, the Korean archaeologists mentioned in this article. This article was created thanks to research financially supported by the Foundation of the University of Łódź, the Institute of Korean Prehistory and the Jeongok Prehistory Museum. 


\section{Archaeological Sites That Are Not Visible in the Landscape}

In fact, there are many different types of archaeological sites. One of the best classifications of types of such "archaeological evidence" is the one proposed by Timothy Darvill: he separated three types of sites ${ }^{2}-$ Standing remains, Earthworks and Buried features (Darvill 1987).

In the case of sites visible in the landscape (standing remains) the creation of archaeological reserves is a relatively easier task than creating an open air museum in a place where only portable artifacts, buried deep in the ground were found. When reconstructing a castle, hillfort or ancient tumulus one can easily capture the entire historical context and create an almost perfect replica of the site in its exact, original location. However, how to deal with presenting open archaeological sites from the earliest periods of human settlement, in which only portable objects were used most often of everyday use, the diversity of functions of which were very small?

On the premises of numerous Paleolithic or Mesolithic archaeological sites, flint tools, remains of hearths, bones and bone tools can be found, all of which have been sporadically scattered, and which are associated with the nomadic lifestyle of our Stone Age ancestors. These sites are called "buried sites" and they are the ones that are most vulnerable to destruction and loss of the context of the find due to their typical invisibility and fragility (Darvill 1987; Lee 2018). An archaeologist reads the history of such a place from objects and their mutual arrangement in a broader context. Often, these sites "end up" described in scientific publications, and the entire collection in a museum warehouse. And what if a site has extremely high scientific value and is extremely important for the world of science? How do scientists manage to show the site in the field in such cases? How can one promote such a place and introduce it into the cultural landscape permanently?

Management of Stone Age sites in South Korea, discovered mainly thanks to rescue research, can be a good example of dealing with all of the problems mentioned above.

2 I) Standing remains: built structures, ranging from the upstanding walls of buildings, or field boundaries, through to stone constructions such as stone circles, standing stones, or burial chambers. These constitute some of the most visually impressive sites in the landscape. 2) Earthworks: soil-covered remains of any sort, which can be seen as surface undulations at ground level. These include the covered remains of ruined buildings or their foundations, as well as banks, mounds, lynchets, dykes, ramparts, ditches, gullies, and hollows. 3) Buried features: soil-covered remains which have no visible surface trace at ground level. The depth of burial varies greatly, not necessarily according to the age of the features, but as a consequence of the circumstances under which the evidence became buried. 


\section{A Brief Introduction to "Buried Site" Archaeology in South Korea}

At the end of the $2 \mathrm{O}^{\text {th }}$ and in the $2 \mathrm{I}^{\text {st }}$ centuries, locating new archaeological sites in South Korea is mainly associated with rescue research. Rescue excavations are carried out before construction of new housing estates and office buildings (Bale 2008; Kwon, Kim 20II; Lee 20I8). All sites that are threatened with destruction are protected by the Cultural Heritage Administration, for which the South Korean government is responsible and headed by the Minister of Culture and Tourism (Bale 2008). Non-compliance with laws imposed by the government is, of course, punished severely.

Today, these regulations are generally known to developers and construction companies, but in the second half of the $20^{\text {th }}$ century, a large increase in the use of land - and consequently excavations, caused conflicts between developers and archaeologists who were demanding protection for archaeological sites (Shoda 2008).

Since then, one of the main trends in National Museum projects cooperating with the South Korean government has been towards the popularization of archaeology and moreover, to promote the protection of cultural heritage among the public. For example, in 1977, at the National Museum of Korea, the "Museum College" program was started, which involved training hobbyists in archaeology, history and the history of art (Kwon, Kim 20II). Students included in the program could gain knowledge at master level, and later work as tour guides for Archaeological Reserves and Museums. This program has been implemented by several Regional, National and University Museums. In addition, an educational and training program on cultural heritage is run by the Korea Land and Housing Corporation - a state-owned company responsible for land development in cities, as well as land maintenance and housing. After receiving a diploma, students can work on rescue excavations, and the program itself is rated highly (Kwon, Kim 20II).

Today, there are practically no conflicts related to protection of archeological sites between developers and archaeologists in South Korea. The successes of the ever-evolving field of public archeology are considerable. Protection of archaeological resources has become a key topic of interest in Korean archeology in particular, as well as in Korean society in general (Lee 2018).

To protect the "buried sites" better, all stakeholders, be they archaeologists, conservators, local or national government, are trying to commemorate the site. If such a site is extremely important, the government and interested parties strive to open an archaeological reserve in this place. In addition, at every prehistoric site, even one that has not been designated a protected zone, a monument is erected to commemorate it. 
Paleolithic Sorori and Suyanggae sites, which were discovered through rescue research, constitute two very important archaeological sites in the context of displaying monuments in the field and educating the public about the Stone Age in South Korea.

\section{Sorori}

The town of Sorori is located in Cheong-won County, Chungbuk Province, South Korea, about I4-I6 kilometers north-east of the city of Cheongju (in the center of the Korean Peninsula). This region is surrounded by relatively low-lying hills, forming a flat valley abundant in farmlands. The valley is crossed by a calmly flowing branch of the Guam River called Miho-cheon.

The Sorori archaeological site was discovered during a site survey carried out in the area designated for the construction of the Ochang industrial complex (Lee, Woo 2003). Archaeological work was led by Professor Lee Yung-Jo from the Institute of Korean Prehistory in Cheongju. During the work performed in the years 1997-1998 and in 200I, late Paleolithic cultural layers were discovered. Also late-Paleolithic flint tools were found at the site (Lee, Woo 2003). However, grains of ancient rice laying among the stone implements were the most important finds. During the excavations at Sorori, 59 grains of rice were found, including I8 grains of ancient rice and 4I "quasi rice" (Lee, Woo 2002; 2003). Ancient rice could have been a predecessor of two species of rice found today: Japanese (Oryza sativa japonica) and Indian (Oryza sativa indica) (Lee, Woo 2002; 2003). The age of sedimentary layers of the site, which was probably the first domesticated rice in the world, was determined by isotope dating (Geochron Lab. USA) and $\mathrm{C}_{4} 4$ (Seoul National University; NFS Arizona AMS Laboratory) (Kim et al. 20I5). For the lower layers, dates of I2.500-I4.800 BP and I6.300-I7.300 BP were determined.

\section{Sorori Monument}

A part of the area of former excavations at the Sorori site has been developed by production halls. Now any trace of past human activity in this place can be seen only in museums (including the Chungbuk National University Museum). There are traces of excavation works in the area next to one of the industrial halls, but they can only be noticed by an experienced archaeologist. This piece of land is the only evidence of excavations carried out in this area. However, 
Professor Lee Yung-Jo and his team sought to commemorate the place where the oldest rice grains were found.

In Korea, erecting monuments in order to commemorate archaeological sites is of vital importance. This tradition is cultivated at all significant sites. Each place has a stone nearby with a designation and a brief description of what was found there. In the case of Sorori, there is also a commemoration stone, but the importance of this place and marking it in a more sublime way was one of the most important goals of local authorities and companies that funded the project.

On November 23, 2016, a large monument commemorating the explored site was erected. The monument was built by the expressway right at the entrance to the industrial complex. It measures about four and a half meters in height and represents a grain of ancient rice, surrounded by bands, each representing a time loop of 2.000 years. There are eight such loops, so one can quickly calculate how many years have passed since the first settlement of Paleolithic societies to the present day.

A local school building, which was closed some time ago, is also under conversion to a Museum of the Sorori site. This place is extremely important for discussion on the world archaeology forum, which is why the stakeholders are concerned about the protection and commemoration of the Sorori site, which constitutes the earliest archaeological evidence of rice cultivation.

\section{Suyanggae}

The archaeological complex of Suyanggae, located at Aegok-ri, Jeokseongmeyon, Danyang County, Chungbuk Province, by the South Han River is another very important site for Korean Prehistory. This archaeological complex was discovered in 1980 when exploring the area where the Chungju Dam was to be built. Construction of the dam began in 1978 and ended in 1985 (Lee, Woo, Lee 20I5). The dam was built in response to the need for regional development but its construction threatened Korea's valuable cultural heritage. As in other developing countries, construction of the dam was once a key to industrialization of Korea (Bale 2008).

The site complex has been explored by archaeologists from the Chungbuk National University Museum (Lee 2007; Lee, Woo 2008; Lee, Woo, Lee 2015). On July 2I, 1980, a team of students and employees from the afore-mentioned museum risked their lives - risked drowning by working during a period of record high rainfall - $750 \mathrm{~mm}$ per $\mathrm{m}^{2}$ (Lee 2007; Lee, Woo, Lee 20I5). These conditions were not friendly for the researchers; however, thanks to them strong 
rain streams washed Paleolithic flint tools from deeper layers of riverside terraces and thus, enabled their registration on the surface.

The Suyanggae complex consists of open sites. Over a dozen excavation campaigns have been carried out so far, and this site is among the most notable archaeological sites in East Asia. Moreover, the site was designated as National Historic Relic No. 398 (Lee 2007; Lee, Woo 2008; Lee, Woo, Lee 20I5). Excavation works included localities I, II, III and VI. Only locality II shows remains of a settlement from the beginning of our era (Lee et al. 20I4). The other sites are mainly flint workshops from the Upper Paleolithic, where the total sum of flint implements is over I00.000. The first works began at locality I in 1983-I985. Immediately after the work was complete, the site was flooded when the Chungju Dam was built. The same happened to locality VI, located more than 3 kilometers from locality I. The research was undertaken there in 2013 , in connection with the construction of another dam on the South Han river. In this place, apart from flint tools and products, fragments of Paleolithic portable art and one pebble stone with engraved lines were found (Suh et al. 20I5; Lee et al. 20I5). However, the most important fact is that the Suyanggae complex was primarily a large flint workshop, used seasonally during the Paleolithic period (Lee 2007; Lee, Woo 2008; Lee, Woo, Lee 2015). These findings undoubtedly testify to the high development of representatives of the Suyanggae culture and the importance of this site for world science.

\section{To Show the Invisible}

Thanks to rescue archaeology, such an important site was saved from destruction by flooding. Consequently, the priority was to ensure the protection of artifacts and the undertaking of accurate documentation. In 2006, the Suyanggae Museum was built. The area devoted for the construction of the museum was thoroughly examined and it turned out that the layers of the third river terrace also included Paleolithic artifacts (Lee, Woo, Lee 20I3). This shows the importance of the so-called "buried sites". As we can see, it is very easy to skip very important pieces of the puzzle, which after assembling can provide answers and further our understanding of such a complex of sites as Suyanggae.

The lack of any traces of huts or shelters observed during excavations did not facilitate the process of land development planning for the construction of an open-air museum. It was necessary to show tangible evidence for the existence of Paleolithic culture in this place thousands of years ago to the local residents, local authorities and investors. 
The artifacts exhibited in the Suyanggae Museum are palpable evidence of the existence of Paleolithic culture in this place. In the museum itself, many original artifacts have been exhibited. Care was also taken to show "themed scenes" from the life of Stone Age hunters and gatherers on multimedia devices and by appropriate arrangement of artificial human figures. The building of the Museum, towering over the meandering southern Han River, together with the surrounding area, with an open archaeological excavation pit and sculptures depicting hunters and gatherers captured during their daily activities constitutes indirect evidence, which is very important for tourists to perceive this place as very important for local and world prehistory.

Education plays a very important role here. From the very beginning the museum team led by Professor Lee Yung-Jo, made sure that knowledge about this important site was disseminated. The Suyanggae museum runs lessons for children from nearby schools, as well as themed events and archeological festivals.

\section{Jeongokri}

Jeongokri is the most famous Paleolithic site on the Korean peninsula, which is another site majestically set into the surrounding landscape.

The Paleolithic site of Jeongokri (Chongokni) is located in the province of Gyeonggi, next to the city of Jeongok-ri, in the basin of the Hantan and Imjin rivers, about 40 kilometers north of Seoul. It is a well-known site among researchers of the oldest human history around the world, thanks to the first discovery of the first Acheulian-type handaxe in Eastern Asia (Bae 20I2; 20I4; 20I5a; 20I5b). Moreover, Jeongokri represents the largest protected archaeological site in South Korea (Lee 20I8).

In 1978, Greg Bowen - an American Air Force pilot, stationed in the city of Dongducheon, near the DMZ (demilitarized zone) about four kilometers from the village of Jeongokri, was going for a walk when he noticed an unusual stone protruding from the ground. The American had some knowledge of the Stone Age archaeology because before joining the Air Force, he had studied Anthropology at Ohio State University (Kang 20I5). The stone was the first Acheulian-type handaxe to be found in Eastern Asia. This find weakened Movius' hypothesis, which had proposed a dichotomous Paleolithic tradition between the East and the West of the world (Bae 20I2; 20I4). In 1979, the site was designated Historic Site No. 265 on account of its academic value (Bae 20I4; 2015a). 
For 30 years, from the discovery to 2009 , 17 research expeditions were carried out. From 1979 and the 1980s, excavations were headed by Professor Kim Wonyong from the National Museum of Seoul University. Subsequent research was carried out by Hanyang University, and Professor Kidong Bae who became a leader of the research. Thanks to interdisciplinary research, the age of the lowest layer containing the oldest stone tools was estimated at 350,000 BP (Bae 20I2; 2015a; 20I5b).

\section{Problems of the Jeongokri Paleolithic Site}

From the very beginning, the researchers of the Jeongokri site had problems with protection of this heritage site (Bae 20I2; 20I5b; Lee 20I8). Local people from the village of Jeongok considered the Paleolithic site as inhibiting economic development and blamed archaeologists and governmental organizations of cultural heritage for neglecting this issue. Town residents made many complaints about strict regulations prohibiting the development of the area around the Paleolithic site. Agriculture was also a problem. The area around the site had to be protected from plowing, which would have caused great damage to new, potential locations of prehistoric artifacts located close to the surface.

The above mentioned problems resulted mainly from the "invisibility" typical for a "buried site". Visitors to this place could only see archaeologists at work, digging deeper and looking for flint tools. Lack of any architectural evidence in the landscape undermined the importance of this site among the non-academic community.

\section{The Largest Paleolithic Festival}

A new method for managing and promoting this place, which is so important for knowledge on human evolution, came in 1993. Professor Kidong Bae initiated an archaeological festival to commemorate the site (Bae 20I4). For the purpose of the festival an exhibition hall was created in a small field station to show the local community basic information about the Jeongokri site (Bae 20I2; 20I5a; 2015b). The festival was a great commercial success, which allowed organization of its subsequent editions in the following years. Until 1998, the festival was carried out without external financial support (neither from the local nor national government) (Lee 20I8).

Jeongok Festivals organized in the I990s attracted attention of the archaeological world. Television broadcasts, newspaper ads promoting the event each year went ever further. Every year, an increasing number of tourists came to 
visit the place. As a result, the local government of Yeoncheon County began providing financial support, and since 2000 , it has been one of the festival's main sponsors (Lee 2108).

Since 2000, over half a million people come to the festival every year. The record was recorded in 2009, where during the scientific festival and concerts, during five days, the reserve area was visited by almost a million tourists (Bae 20I2; 20I5a; 20I5b). Not only the Paleolithic site and archeology itself started to be promoted, but also local folklore, cuisine and Korean tradition. Guests from all over the world were invited to the event. Also concerts of the biggest K-pop stars were organized.

In the center of a huge festival square, located in a protected archaeological area, a place for scientists has been exposed. Representatives of museums and prehistoric reserves from all around the world, including Japan, Germany, Lithuania, Spain and even Chille or Tanzania are invited to the archaeological festival in Jeongokri. During these few festival days, experimental archeology workshops, scientific games for children, as well as seminars and presentations for adults are conducted. The main theme of the presentations is the protection of cultural heritage, ways of preserving archaeological discoveries and showing scientific achievements of the invited archaeologists.

\section{The "Spaceship-Like" Museum and the Surrounding Area}

The first successes of the festival led to an idea to build a museum at the Jeongokri site and create an archaeological park for visitors. In 2007, the design of the building in which the museum would be housed was selected, and its creators included known architects from the French company "X-TU". The facility was opened on April 20II (Bae 20I2; 20I5b; Lee 20I6).

The museum building resembles a spaceship that landed on the edge of a basalt cliff. The round, aerodynamic silhouette looks like a machine from science-fiction movies, and the shiny walls of the building reflect the beauty of the surrounding landscape like mirrors. Such a design is not accidental. The main slogan that stimulates visitors' imaginations is: Gate to Prehistoric Ages, and the design of the building is like a "time machine" transporting tourists back to the earliest times, during which man evolved through all his forms, as the main exhibition entitled: Grand March of Human Evolution shows (Lee 20I6). To stay in harmony with the landscape, the building was designed to be fairly flat and rounded. Thanks to this, visitors, regardless of whether they are in the museum or on its roof, can always admire the surrounding geological landscape (Bae 20I2; Lee 2016). 
The inside of the museum was designed in such a way that the tourists could move freely between the exhibitions. Individual sections are not strictly separated by walls. In this facility, the latest technologies have been applied, such as interactive systems or three-dimensional (3D) exhibitions, which constitute an interesting way to educate people about our ancestors and about the environment in which they used to live in prehistoric times. There are also many attractions for children - among others, the "Kid's Archeo-Lab" where children can learn about secrets of archeology work (Bae 20I5b). In the main hall there is a permanent exhibition, Grand March of Human Evolution, which shows reconstructions of most forms of hominids from Sahelantropus to Homo sapiens. Of course, artifacts from this Paleolithic site are also exhibited.

Near the main museum facility, a building was built to protect the authentic archaeological remnant of the archaeologists' work. An excavation pit containing actual stratigraphy and reconstructed stone artifacts, lying exactly as they were found by scientists during their work, is intended to make tourists aware of the fact that relics of the activity of antecessors were actually found in this place (Bae 20I2; 20I5b; Lee 20I6).

The Museum and Archaeological Park in Jeongokri management is also planning to restore two different types of vegetation within the reserve: endemic vegetation of the temperate zone and glacial vegetation that occurred there thousands of years ago (Bae 20I2). The glacial nature of the vegetation was to be reconstructed by planting pine and birch species that grow at high altitudes. The initiated experiment aims at, though to a small extent, to reflect the ancient nature and character of this place.

\section{Visible is What is Invisible}

The Jeongok Museum is one of the best known institutions of this type in the Far East. Its success that has been achieved in just a dozen or so years, from the first festival in 1993 to the construction of a worthy museum building in $20 I$ and is due primarily to the first-class way the site has been managed and (or perhaps above all) the manner in which the community, the local and state government were convinced that the Jeongokri site is of great importance to the world science and to the development of the region.

The support of the government and private entrepreneurs was the most important goal (Lee 2018). Purchase of surrounding areas to provide protection against destruction of this valuable archaeological zone was a priority.

At this point, one can start wondering if this whole "festival envelope" is not a more attractive element than the prehistory of Jeongokri itself. It is 
possible that for some tourists these festival details are important, but it should be remembered that the advertising campaign is focused on encouraging tourists to learn about the oldest human history in the Far East. In addition, in the museum and in the reserve, reconstruction of artifacts and teaching methods are prepared by outstanding specialists - archaeologists, reconstructors and didactics. Many attractions can attract, but it is the history of the place that will stop and intrigue the tourist for longer.

Positive results were obtained thanks to the determination of people who will be forever associated with the history of creation of the Jeongok monument. The monument consists of a museum building, remains of real archaeological excavations, the whole area with a beautiful geological landscape and for the festival, which is well known to and remembered by an increasing number of tourists. This is a monument, which was erected in honor of the first ancestors who arrived in the Korean Peninsula. Without a doubt, the spirit of the ancestors watching over this place is visible and perceptible.

\section{Conclusions}

The rapid industrialization of the Korean Peninsula allowed locating "buried sites". Despite conflicts between archaeologists and developers and local communities, a certain consensus was achieved in South Korea giving an opportunity to protect and commemorate important Stone Age sites.

The monumentalisation of prehistoric archaeological sites has become widespread in Korea, especially where no remains of prehistoric living that is visible in the landscape have survived. Creating Archaeological Parks, with the consent of the local population often with objections to such undertakings and gaining political support of local authorities, which also must adapt to the needs of the society, is a very difficult task.

The patriotic factor plays a significant role here. For the general public, getting to know the oldest history of the Korean Peninsula is very important due to their attachment to tradition and culture. The best way to learn a story is to get in touch with it. The most difficult task is to show the sites without an architectonical form visible in the field. The most important issue for such an undertaking is having a strong presentation concept to exhibit an archaeological site, which greatly simplifies learning about the most ancient aspects of history. South Korea, and especially the three sites from the different Paleolithic periods discussed in this article, constitute a very good example of public education and of how to convey to the public the huge significance of archaeological Stone Age sites. 


\section{Bibliography}

Bae K. (2012), Public Archaeology of the Jeongok Paleolithic Site. Festival, Prehistoric Heritage Education, Site Preservation and Museum, Hagyŏn Munhwasa, Seoul.

Bae K. (2014), The Significance of Archaeological Research in South Korea for Human Evolution. The Case of Chongokni Paleolithic Site, Regional Cooperative Priorities in Relation to Research and Conservation, [in:] N. Sanz (ed.), Human Origin Sites and the World Heritage Convention in Asia, UNESCO, Paris (World Heritage Series, 39), p. 35-52.

Bae K. (2015a), Paleolithic Archaeology and Social Sustainability: Research, Festival and Preservation of Chongokni Paleolithic Site in Korea, [in:] Y.-J. Lee, J.-Y. Woo, S.-W. Lee, K.-W. Lee (ed.), The 20 $0^{\text {th }}$ (2) International Symposium for Celebration of the $30^{\text {th }}$ Anniversary of the $1^{\text {st }}$ Site Excavations. Suyanggae and Her Neighbours in Korea, Institute of Korean Prehistory, Cheongju, p. 23-38.

Bae K. (2015b), Museum and History of the Jeongok Paleolithic Site - Research, Prehistoric Festival and Preservation, Jeongok Prehistory Museum.

Bale M.T. (2008), Archaeological Heritage Management in South Korea: The Nam River Dam Project, [in:] M.E. Byington (ed.), Early Korea, vol. I, Reconsidering Early Korean History through Archaeology, Early Korea Project, Korea Institute; Harvard University, Cambridge Mass., p. 213-233.

Darvill T. (1987), Ancient Monuments in the Countryside. An Archaeological Management Review, English Heritage, London.

Hensel W. (1973), Archeologia żywa, Wydawnictwa Artystyczne i Filmowe, Warszawa.

Kang H.K (2015), US Airman's Love of Rocks Results in Shift in Archaeological Studies: The Korean Times, 30.11.2015, http://www.koreatimes.co.kr/www/ nation/2019/06/113_192068.html.

Kim J.Y., Lee Y.-J., Woo J.Y., Lee S.W., Oh K.Ch. (2015), Analysis and Implications of Geological Environment of the World's Oldest Sorori Rice Seed, [in:] Y.-J. Lee, J.-Y. Woo, K.-W. Lee (ed.), International Symposium for 2015 Cheongwon Organic Life Festival-Cheongju Sorori Rice and the City of Life \& Culture, Institute of Korean Prehistory, Cheongju City, p. 75-77.

Kwon O.Y., Kim M.J. (2011), Public Archaeology in Korea: A Duet of Popularity and Nationalism, [in:] K. Okamura, A. Matsuda (ed.), New Perspectives in Global Public Archaeology, Springer, New York-London, p. 87-94, https://doi. org/10.1007/978-1-4614-0341-8_7

Lee H. (2016), Jeongok Prehistory Museum. Museum Guide Book, The Jeongok Prehistory Museum, Jeongok-ri (Korea).

Lee H.J. (2018), Archaeological Resource Management in South Korea. Developing a Holistic Management Planning Model for Buried Archaeological Sites, Doctoral thesis $(\mathrm{PhD})$, University College London. 
Lee K.W., Lee Y.-J, Woo J.Y., Lee S.W., Ahn J.H. (2015), Engraved Stones Found at Suyanggae Locality VI: Signs of Modern Human Behavior, [in:] Y.-J. Lee, J.-Y. Woo, S.-W. Lee, K.-W. Lee (ed.), The 20 $0^{\text {th }}$ (2) International Symposium for Celebration of the $30^{\text {th }}$ Anniversary of the $1^{\text {st }}$ Site Excavations. Suyanggae and Her Neighbours in Korea, Institute of Korean Prehistory, Cheongju City, p. 299-312.

Lee Y.-J. (2007), Suyanggae: Why So Important?, [in:] N. Drozdov, Y.-J. Lee (ed.) The $12^{\text {th }}$ International Symposium Suyanggae and Her Neighbours. Prehistoric Migrations in Eurasia and America, Krasnoyarsk State Pedagogical University Named after V.P. Astafiev; Institute of Korean Prehistory, Krasnoyarsk-Cheongju, p. 7-23.

Lee Y.-J., Woo J.Y. (2002), On the Oryza sativa and Peat Layers from the Paleolithic Sorori Site in Cheongwon, Korea, [in:] Y.-J. Lee, J.-Y. Woo (ed.), The Th International Symposium: Suyanggae and Her Neighbours, Chungbuk National University Museum, Cheongju City, p. 269-294.

Lee Y.-J., Woo J.Y. (2003), The Oldest Sorori Rice 15,000BP: Its Findings and Significance, [in:] Y.-J. Lee, W.-S. Kim (ed.), The $8^{\text {th }}$ International Symposium for $20^{\text {th }}$ Anniversary of Suyanggae First Excavation: Suyanggae and Her Neighbours, Institute for Jungwon Culture; Chungbuk National University; Hakyoun Moonwhasa Press, Seoul, p. 89-98.

Lee Y.-J., Woo J.Y. (2008), Suyanggae: Why So Important (II), [in:] Y.-J. Lee, M. Ambiru, K. Shimada, K. Otani (ed.), The $13^{\text {th }}$ International Symposium for Commemoration of the 25 $5^{\text {th }}$ Anniversary of Suyanggae Excavation: Suyanggae and Her Neighbours in Kyushu, Institute of Korean Prehistory; Saitobaru Archaeological Museum of Miyazaki Prefecture, Cheongju-Saito, p. 37-53.

Lee Y.-J., Woo J.Y., Lee S.W. (2013), Suyanggae: Why So Important (VI) - with New Findings from Loc.III, [in:] G. Xing, N.I. Drozdov, L. Domańska, J.-Y. Woo (ed.), Commemoration Int'l Symp. for the $90^{\text {th }}$ Anniversary of Shuidonggou Discovery and the $18^{\text {th }}$ Suyanggae and Her Neighbours for 50 Years of Prof. Yung-jo LEE's Paleolithic Study: Shuidonggou and Suyanggae, Institute of Korean Prehistory; Institute of Vertebrate Paleontology and Paleoanthropology, Cheongju City-Beijing, p. 124-127.

Lee Y.-J., Woo J.Y., Lee S.W. (2015), Suyanggae: Why So Important (IX)?: 30 Years of the Suyanggae Complex, [in:] Y.-J. Lee, J.-Y. Woo, S.-W. Lee, K.-W. Lee (ed.), The $20^{\text {th }}$ (2) International Symposium for Celebration of the $30^{\text {th }}$ Anniversary of the $1^{\text {st }}$ Site Excavations. Suyanggae and Her Neighbours in Korea, Institute of Korean Prehistory, Cheongju City, p. 247-262.

Lee Y.-J., Woo J.Y., Lee S.W., An J.H. (2014), Suyanggae: Why So Important (VII)? - with the Newly Excavated Loc.VI, Suyanggae Site, [in:] L. Domańska, Y.-J. Lee, J.-Y. Woo (ed.), The $19^{\text {th }}$ International Symposium Suyanggae and Her Neighbours in Poland. Lodz and Suyanggae, Institute of Archaeology. University of Lodz; Institute of Korean Prehistory, Lodz-Cheongju City, p. 191-197. 
Rajewski Z. (1964), Pokaz zabytków w terenie, "Wiadomości Archeologiczne”, 30 (1-2), p. 102-116.

The Reconstructed Past. Reconstructions in the Public Interpretations of Archaeology and History (2004), J.H. Jameson Jr (ed.), AltaMira Press, Walnut Creek.

Shoda S. (2008), A Brief Introduction to Rescue Archaeology in South Korea, [in:] M.E. Byington (ed.), Early Korea, vol. I, Reconsidering Early Korean History through Archaeology, Early Korea Project, Korea Institute; Harvard University, Cambridge Mass., p. 202-205.

Suh H.S., Lee Y.J., Woo J.Y., Lee S.W., Park J.M., Ahn J.H., Lee K.W., Joo Y.S., Choi W.H., Yang H.J. (2015), Measurement of Dimension and its Related Measurands of the Pebble Stone with Engraved Lines Excavated from Loc.VI of Suyanggae Site, Korea, [in:] Y.-J. Lee, J.-Y. Woo, S.-W. Lee, K.-W. Lee (ed.), The 20th (2) International Symposium for Celebration of the $30^{\text {th }}$ Anniversary of the $1^{\text {st }}$ Site Excavations. Suyanggae and Her Neighbours in Korea, Institute of Korean Prehistory, Cheongju City, p. 283-297.

\section{Summary}

Stone Age Archaeological Sites in the Landscape. Monumentalisation of Sites on the South Korea Example

The aim of the article is to show selected ways of presenting Stone Age archaeological sites in the landscape. The forms of prehistoric archaeological sites monumentalisation in South Korea served as an example here. Displaying Stone Age sites in the landscape is popular in Korea, especially where no remains of former human activity visible in the landscape have been preserved. Establishing reserves, museums and monuments nearby an explored archaeological site is very important for the majority of stakeholders in South Korea. Patriotic factor plays an important role here as for the society in general getting to know the oldest history of the Korean Peninsula is very important, due to the people's attachment to their tradition and culture. The sites described in this article are among the best-known by the researchers and the general public in South Korea. The Sorori site, showing first attempts at rice domestication, was discovered thanks to site prospection carried out before the construction of an industrial complex. The Suyanggae site is the biggest Palaeolithic flint workshop located in the Korean Peninsula, discovered during the rescue excavations connected with construction of a dam on the South Han River. The Jeongok site - one of the most important sites in Eastern Asia due to the discovery of the first Acheulian-type 
handaxe outside the borders of the Movius line - was accidentally discovered by an American pilot from the nearby military base. All three sites of prehistoric human activity are very important for the world of science as well as for entities responsible for the protection of cultural heritage, being a model for ways of managing museums, reserves, and culture parks established at excavation sites. What is more, in the article a short presentation of developing rescue archaeology is provided, related to rapid industrialization of South Korea.

Keywords: Archaeology of South Korea, monumentalisation, buried sites, Sorori site, Suyanggae site, Jeongok Paleolithic site

\section{Streszczenie}

\section{Stanowiska archeologiczne z epoki kamienia w krajobrazie. Monumentalizacja stanowisk na przykładach z Korei Południowej}

Celem artykułu jest przedstawienie wybranych sposobów prezentowania stanowisk archeologicznych z epoki kamienia w krajobrazie. Jako przykład posłużyły tu formy monumentalizacji prehistorycznych stanowisk archeologicznych w Korei Południowej. Pokaz stanowisk z epoki kamienia w krajobrazie jest szeroko rozpowszechniony w Korei, szczególnie tam, gdzie nie zachowały się żadne pozostałości dawnej działalności ludzkiej w postaci form terenowych. Tworzenie rezerwatów, muzeów i pomników przy przebadanym stanowisku archeologicznym jest bardzo ważne dla większości interesariuszy w Korei Południowej. Dużą rolę odgrywa tu czynnik patriotyczny, ponieważ dla ogółu społeczeństwa istotne jest poznanie najstarszej historii Półwyspu Koreańskiego ze względu na przywiązanie do tradycji i kultury. Stanowiska opisane w artykule są jednymi z najbardziej znanych wśród naukowców i szerokiej publiczności w Korei Południowej. Stanowisko Sorori, wykazujące ślady pierwszych prób udomowienia ryżu, zostało odkryte dzięki prospekcji terenowej przeprowadzonej przed budową kompleksu przemysłowego. Stanowisko Suyanggae - największy paleolityczny warsztat krzemieniarski zlokalizowany na Półwyspie Koreańskim - odkryto podczas badań ratunkowych związanych z budową tamy na południowej rzece Han. Stanowisko Jeongok - jedno z najważniejszych stanowisk Wschodniej Azji z powodu odkrycia pierwszego pięściaka typu aszelskiego poza granicami linii Moviusa - zostało odkryte przypadkowo przez amerykańskiego lotnika stacjonującego w okolicznej bazie wojskowej. Wszystkie trzy miejsca pradziejowej działalności człowieka są bardzo ważne dla świata nauki oraz dla podmiotów zajmujących się ochroną dziedzictwa kulturowego, stanowiąc wzorzec dla sposobów zarządzania 
powstałymi w miejscu wykopalisk muzeami, rezerwatami i parkami kulturowymi. Ponadto w artykule zawarto krótkie przedstawienie rozwijającej się archeologii ratowniczej, związanej z bardzo szybką industrializacją Korei Południowej.

Słowa kluczowe: archeologia Korei Południowej, monumentalizacja, stanowiska niewidoczne w terenie, stanowisko Sorori, stanowisko Suyanggae, paleolityczne stanowisko Jeongok

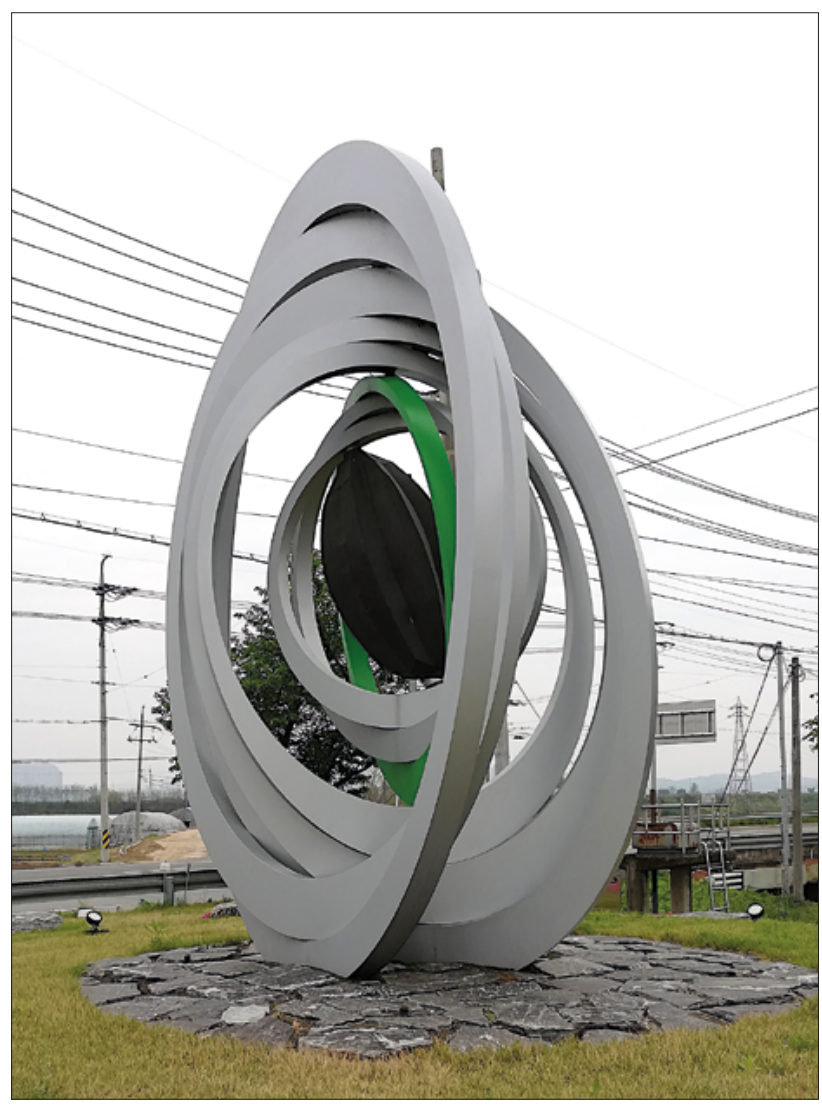

Fig. 1. Sorori monument. Photograph by M. Bartczak. 


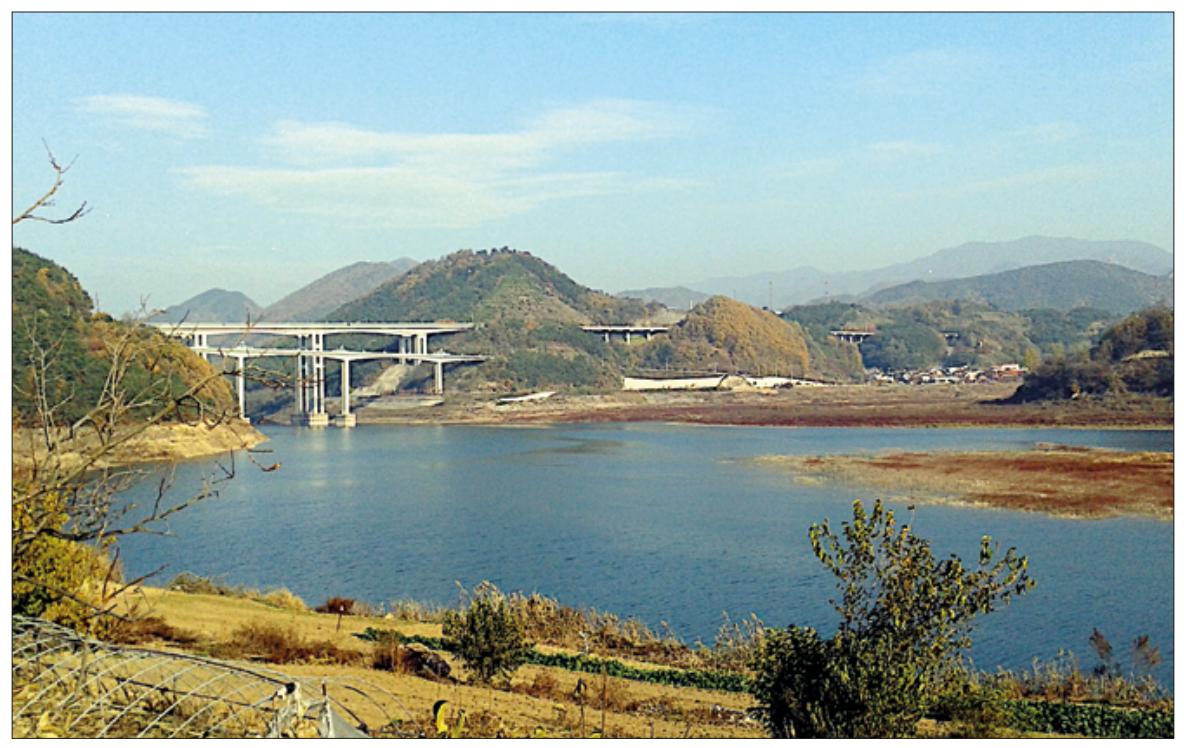

Fig. 2. Landscape nearby Suyanggae site complex (South Han River). Photograph by M. Bartczak.

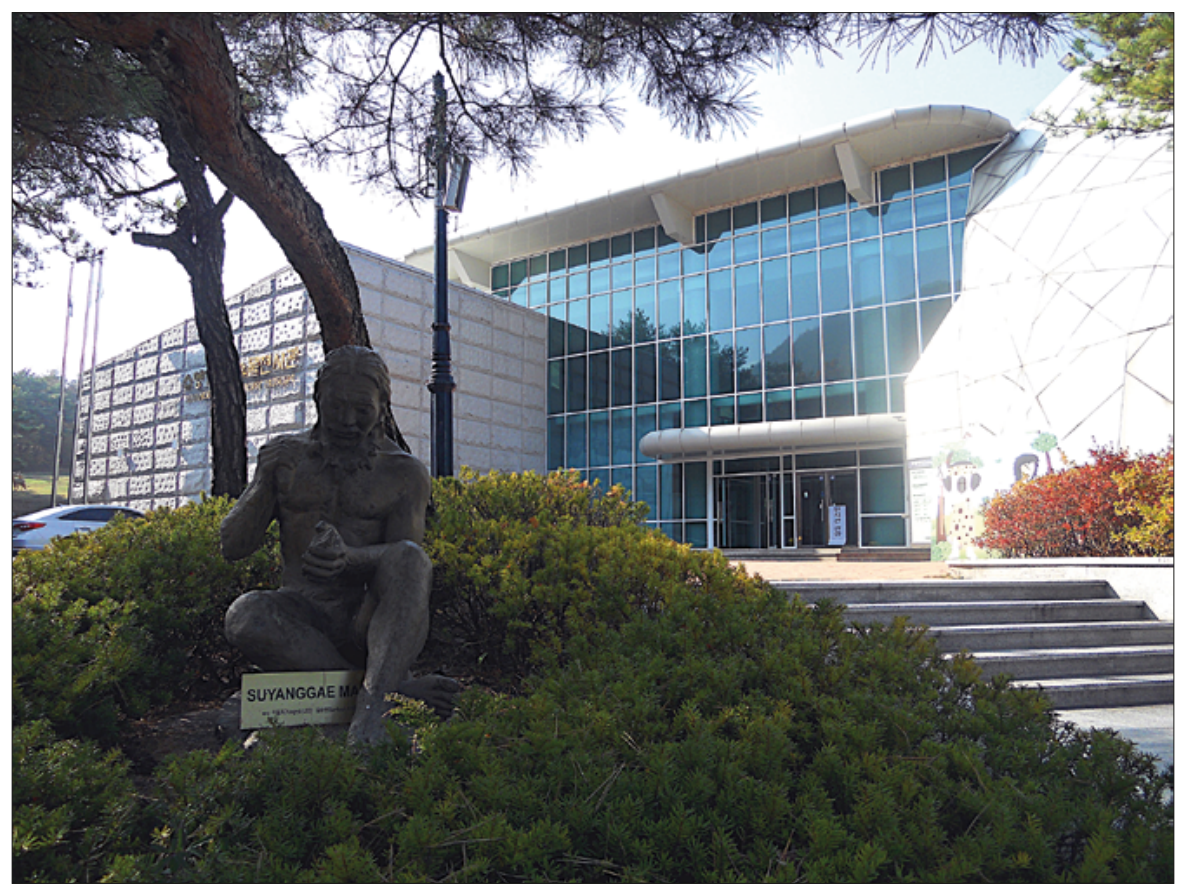

Fig. 3. Suyanggae Museum. Photograph by M. Bartczak. 


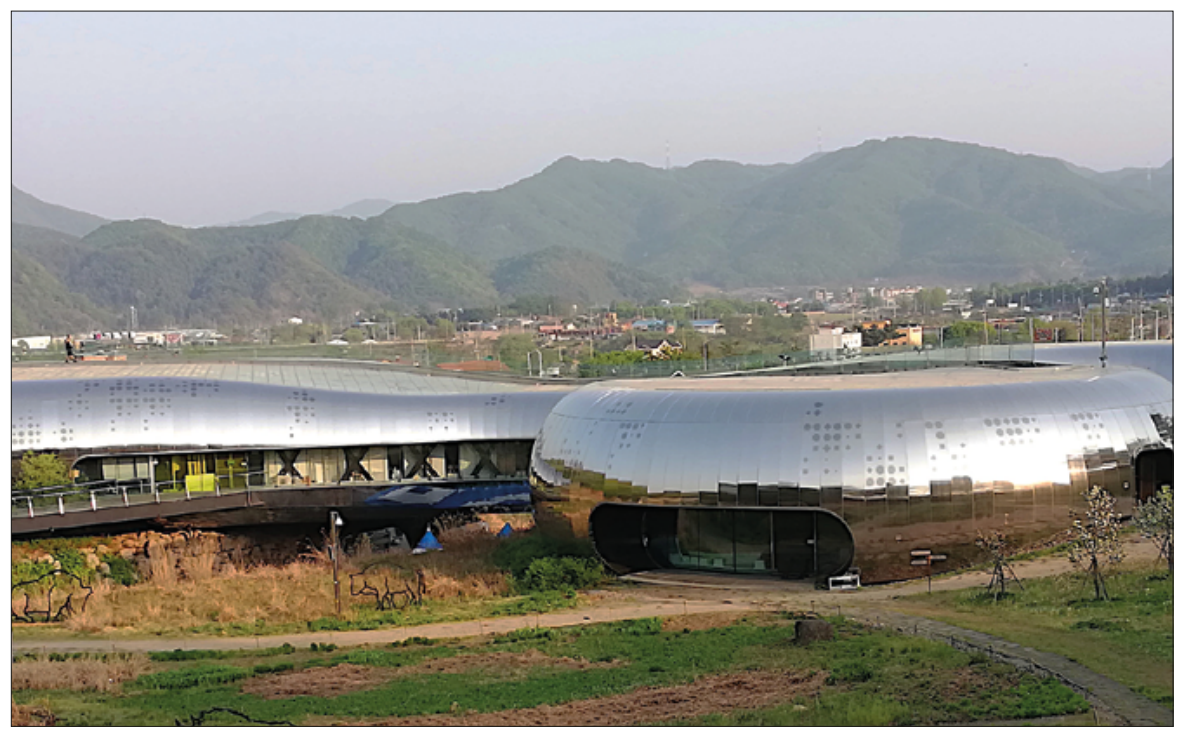

Fig. 4. Jeongok Museum. Photograph by M. Bartczak.

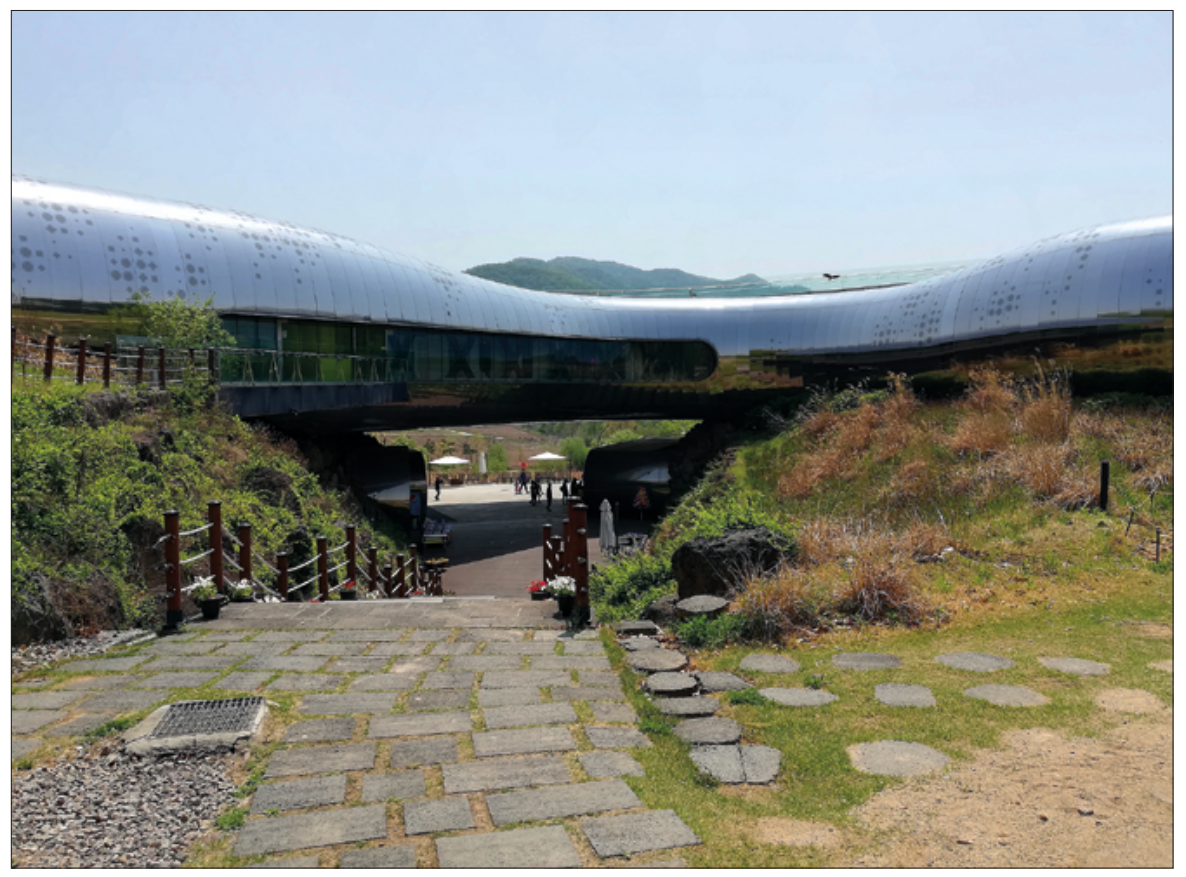

Fig. 5. Jeongok Museum. Photograph by M. Bartczak. 


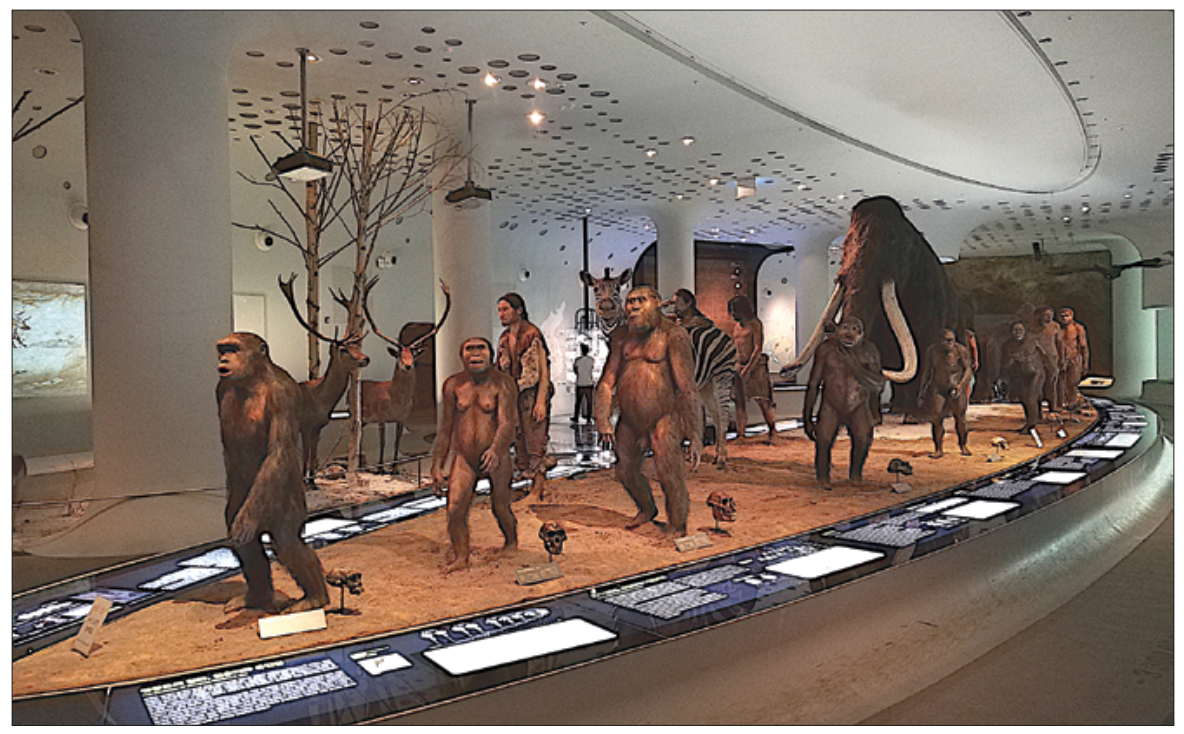

Fig. 6. The main exhibition entitled Grand March of Human Evolution at the Jeongok Museum. Photograph by M. Bartczak.

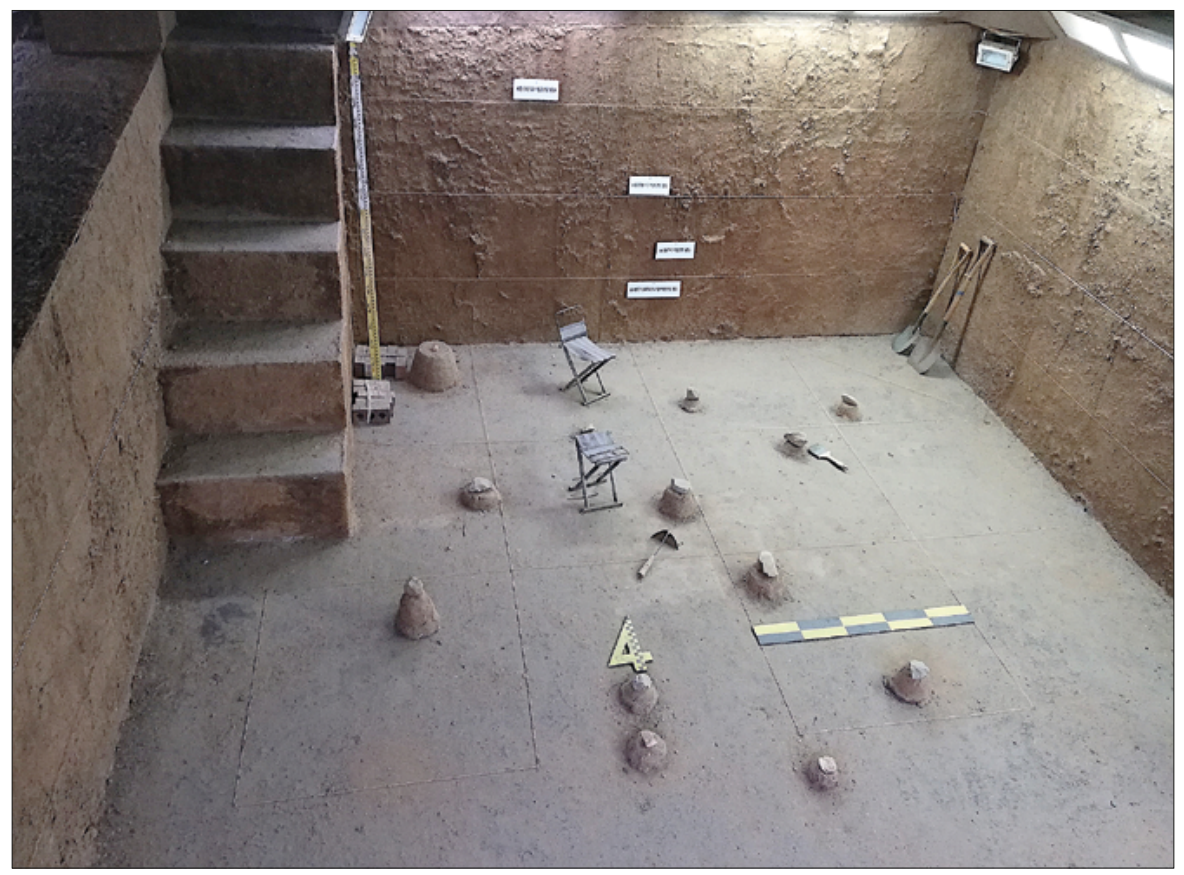

Fig. 7. A remnant of the archaeologists' work - the excavation pit. Photograph by M. Bartczak. 


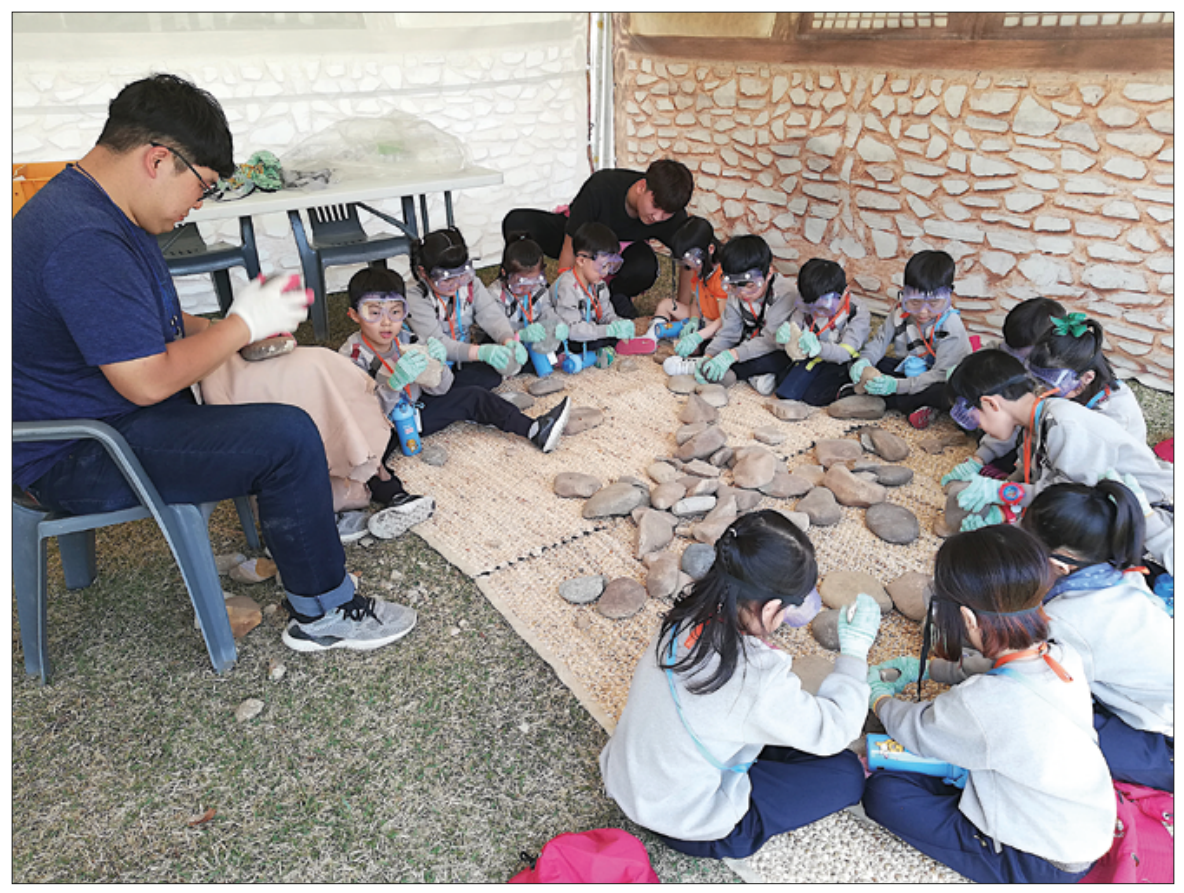

Fig. 8. Stone tool making workshops for children, at Jeongok Festival. Photograph by M. Bartczak. 